UDC 341.238(437:569.4)"1947/1949"

CERIF: T330, H250, H300

DOI: 10.51204/HLH_20111A

Mgr. Vojtěch VRBA*

\title{
FROM CZECHOSLOVAKIA TO THE STATE OF ISRAEL: INTRODUCTION TO LEGAL ASPECTS OF CZECHOSLOVAK HELP TO THE STATE OF ISRAEL IN 1947-1949
}

The paper introduces the reader to basic legal aspects of Czechoslovak help to the State of Israel in 1947-1949. During this time, Czechoslovakia exported arms, ammunition, fighter planes and other war material to the Jewish community in the Middle East. There was also a significant number of volunteers, who underwent various training courses in Czechoslovakia. These courses included training of pilots, aviation mechanics, paratroopers etc. All these operations had their legal merits and aspects. The paper analysis these aspects in general. The sources used in the paper are legal and archival documents and interviews, along with secondary sources and literature, both memoirs and historiographic.

Keywords: Czechoslovakia. - Israel. - Legal history. - Israel Independence War.

During 1948, a war was raging in the Middle East. In it, the small nation of Israel stood like biblical David against Goliath comprised of the surrounding Arab states. The "sling" was at that time provided mainly by

* Ph.D. student at the University of West Bohemia in Pilsen Faculty of Law, vrbav@kpo.zcu.cz.

The paper was written under the project "ZČU SGS-2020-025 Law in the Course of Time 3", realised at the Department of Legal History of the University of West Bohemia in Pilsen Faculty of Law. 
another small nation, thriving for many centuries far away from the Middle East. Czechoslovaks, with their home situated in the centre of Europe.

This paper's aim is to describe circumstances surrounding the story of the "sling". Arms shipments and services provided by Czechoslovakia were contractually secured with emphasis on maximising the legality of their every aspect, as will be briefly shown. Additionally, each and every contract negotiated between Czechoslovakia and the Jewish Agency and/ or Israel should be observed as valid, legal and without any legal fault, both nowadays and at the time of their creation. To support these claims, archival sources were examined, interviews with contemporaries were conducted, literature and legal sources such as individual Acts, Treaties, regulations etc. were thoroughly studied. The main aim of this paper, however, is to present the legal issues regarding these somewhat obscure events of 1947-1949 to the general public, rather than offer a thorough scientific examination of an individual legal document or case - instead, this work is crucial for providing a context for such an analysis and examination. Because, as it will be shown, there are many cases and many legal documents to examine, and each of them would make a story of its own. Speaking of stories, let us start with one.

On a foggy Sunday on December $19^{\text {th }}, 1948$, there was a big fuss at the small airport of Kunovice, near the town of Zlín in Czechoslovakia. A thorough pre-flight check was performed on six Supermarine Spitfire Mk. IXE fighters, modified to gradually reach two locations: firstly, the Nikšić airfield in Yugoslavia; secondly, the State of Israel. Code name of the operation: Velvetta II. The pilots: volunteers from the United States, South Africa and Israel itself, offering their services to help the young nation. ${ }^{1}$ Amongst them, there were three outstanding figures: a veteran of the Pacific operations, George Lichter, and two "boys", as George used to call them, Moti Fein ${ }^{2}$ and Dani Shapira ${ }^{3}{ }^{4}$

1 For the overseas volunteers, in Israeli sources usually known as "Machal", see Yaacov Markovitzky, Machal: Overseas Volunteers in Israel's War of Independence, Jerusalem 2003, [Internet Edition 2007.], http://www.palyam.org/Volunteers/MachalPdf.pdf, last visited on 1.6.2020.

2 Later well-known as Moti Hod, the Commander of the Israeli Air Force during the 1967 Six-Day War.

3 A well-distinguished pilot of the Israeli Air Force who flew in every war Israel was part of, and the first Israeli to fly a Dassault Mirage III fighter plane.

4 Schlomo Aloni, Brian Cull, David Nicole, Spitfires Over Israel, Grub Street, London 1994, 293; Eliezer Cohen, Israel's Best Defense: The First Full Story of the Israeli Air Force, Orion Books, New York 1990, 48; Vic Shayne, Ups and Downs With No Regrets: The Story of George Lichter, iUniverse, Bloomington 2012, 337; Alex Yofe, Spitfire Mk. IX in the Israeli Air Force Service 1948-1956, White Crow, San Jose 2007, 13; Robert Gandt, Angels in the Sky, W. W. Norton \& Co. Ltd., New York 2017, 313; Above and 
It was not the first time that George was preparing for takeoff to Yugoslavia. It was only the day before that he, together with Sam Pomerance - in charge of Spitfires' modifications, Bill Pomerantz, and others took off and headed south. In order to enable the Spitfires to reach both destinations, every nonessential piece of equipment was removed and replaced with spare fuel tanks. ${ }^{5}$ To maximise the chance of success of the operation, an order to fly in close formation was given. ${ }^{6}$

But a snowstorm hit them, and they could either try to pass through it, or turn back. George and the others chose the latter, while Bill Pomerantz and Sam Pomerance went on. The former managed to perform an emergency landing on the coast of Yugoslavia. Sam Pomerance crashed into a mountain and died on impact. ${ }^{7}$ The snowstorm passed, now, and it was George's turn to lead the squadron on again. The problems, however, were looming on the horizon and it was not long before they occurred.

The weather worsened quickly after they took off, once again. Suddenly, Dani lost contact with both his leader - George - and the wingman - Moti. He had not learnt dead reckoning and instrument flying, he did not know where he should be headed, and, apart from some rather alarming information, he could not read where he was heading at all. "I knew that I was turning right and that I was descending, but I had no idea where I was going..."

Dani started to prepare for leaving the plane. He opened the cockpit.

"...and then, suddenly, through the clouds, there was George. He found me. He waved at me and took me and lead me up all the way to others. He found me.",

And so it came that all six Spitfires safely reached Nikšić that day.

This unbelievable story from the winter of 1948, told to us by Dani Shapira on our visit to Haifa in 2018, was one of many manifestations of events set in motion thousands of kilometres away from sunny Israel - in

Beyond [movie], directed by Roberta Grossman, USA 2014, 01:09:00 et seq; Zdeněk Klíma, Československý podíl na vzniku izraelského vojenského letectva a jeho operační činnosti v 1. izraelsko-arabské válce: proseminární práce, Praha 1995, 115.

5 Avi Cohen, The History of Israeli Air Force in The War for Independence 15 July 1948 - 15 October 1948 (hebrew), Ministry of Defence, Tel-Aviv 2004, 474; Z. Klíma, 99.

6 From a personal interview with Dani Shapira, Haifa 25. 3. 2018; S. Aloni, B. Cull, D. Nicole, 293-294; V. Shayne, 337; R. Gandt, 314; Above and Beyond, 01:10:30 et seq.

7 S. Aloni, B. Cull, D. Nicole, 293; E. Cohen, 47; V. Shayne, 336; A. Yofe, 13; R. Gandt, 313; Z. Klíma, 115.

8 From a personal interview with Dani Shapira; S. Aloni, B. Cull, D. Nicole, 293-294; V. Shayne, 337; R. Gandt, 314; Above and Beyond, 01:10:30 et seq.

9 From a personal interview with Dani Shapira; S. Aloni, B. Cull, D. Nicole, 294; R. Gandt, 314; Above and Beyond, 01:11:30 et seq. 
a small country in the heart of Europe, in Czechoslovakia. Czechoslovakia itself lived through major changes between 1947 and 1949. The struggle between the "old" republican ways and the "new" communist ones was going on at full-tilt since the war and it culminated in February 1948, when the Communist Party of Czechoslovakia finally seized power in a coup détat. The country started to gradually shift to the East. Although some contracts between the Jewish community of Palestine and Czech factories were negotiated and closed before February, they seemed to be unaffected by the inner struggles. And new ones were on their way, fully endorsed by the new regime.

In the end, Czechoslovakia sold fighter planes (Avia S-199 and Spitfire Mk. IXE), rifles (Mauser Kar 98k), machine guns (Mauser MG-34 and ZB-37), and ammunition to the Jewish community of Palestine and, subsequently, the State Israel, and provided training for pilots, ${ }^{10}$ mechanics, ${ }^{11}$ paratroopers ${ }^{12}$, and even a whole unit of volunteers known as "the Hagana Brigade"13. This way, about 50000 rifles, 6000 machine guns, millions of rounds of ammunition, 25 Avia S-199 planes and about 60 Spitfire planes left Czechoslovakia for Israel. ${ }^{14}$

10 Regarding the promise from May $5^{\text {th }}, 1948$, see Archiv Bezpečnostních složek (Archive of Security Services, further as "ABS"), 425_360_6_0005; Marie Bulínová et al. (eds.), Československo a Izrael 1945-1956: dokumenty, Ústav pro soudobé dějiny AV ČR, Praha 1993, 99, No. 26; Z. Klíma, 130 et seq.

11 Also, regarding the promise from May $5^{\text {th }}, 1948$, see ABS 425_360_6_0005; Bulínová et al., 98, No. 26; Arnold Krammer, The forgotten friendship: Israel and the Soviet Bloc, 1947-53, University of Illinois Press, Urbana 1974, 92.

12 ABS 425_360_6_0005; Bulínová et al., 99, No. 26.

13 About the brigade, see Jiří Dufek, Karel Kaplan, Vladimír Šlosar, Československo a Izrael v letech 1947-1953, Doplněk, Praha 1993, 59. et seq; J. Dufek, K. Kaplan, V. Šlosar, 174-189; Ivo Pejčoch, "Výcvik př́slušníků brigády Hagana v Československu”, Historie a vojenství, 60/2011, 4-21; also from testimonies, see Yad Vashem, The World Holocaust Remembrance Center, Archives, O.59, Collection of Testimonies and Documents about the Participation of Czechoslovakian Jewry in the War against Nazi-Germany (further as "YAD VASHEM ARCHIVES, O.59"), File No. 9, Božena Elisheva Hermann-Cohen, interview from 17.1.1973, 1; Yad Vashem, The World Holocaust Remembrance Center, Archives, O.59, Collection of Testimonies and Documents about the Participation of Czechoslovakian Jewry in the War against Nazi-Germany, File No. 71, Samson Šachta Schaechter, interview from 14.4.1973, 13; Interview with MUDr. Michael Lavi roz. Lebovič (1913-2015.), Adam Hradilek (interviewer), Pamět národa, cit. 25.2.2019, Ascalon, 7. 6. 2006. <https://www.pametnaroda.cz/cs/lavi-roz-lebovic-michael-1913>; Vilém Kahan, "Vilém Kahan par lui méme (extraits des entretiens de 1984)", Bibliography of the Communist International (19191979), E.J. Brill, New York 1990, 58; Karel Bartošek, Český vězeň: svědectví politických vězeňkyn̆ a věznnu let padesátých, šedesátých a sedmdesátých, Paseka, Praha 2001, 136.

14 Amitzur Ilan, The origin of the Arab-Israeli arms race: arms, embargo, military power and decision in the 1948 Palestine war, New York University Press, New York 1996, 173; see also Z. Klíma, 235. et seq. 
As outstanding and generous these events may appear, it was not any sudden collective change of heart for the Czechoslovaks. The state - and its representatives - was well known to be sympathetic towards the Jewish pursuit of a state in Palestine for a long time. After all, it was the notable first president of Czechoslovakia, Thomas Garrigue Masaryk, who visited Palestine as the first head of a state in history. Although his visit was planned to be incognito, the rumour of it easily and quickly spread among Palestine's inhabitants and he was welcomed, especially by the Jewish community, as any head of state on an official visit. ${ }^{15}$ It was no wonder - his stance against antisemitism was already known from his engagement in the so-called "Hilsner Affair", when he valiantly defended Hilsner, a Czech Jew, unlawfully accused of the ritual killing of Anežka Hrůzová. ${ }^{16}$ To honour all his accomplishments in his life-long fight against antisemitism, a kibbutz in Israel (or the contemporary British Mandate of Palestine) was even established in 1933 - Kfar Masaryk. ${ }^{17}$

Thomas was not the only Masaryk that supported the "Jewish cause". His son, Jan, together with Karel Lisicky, advocated for it in the forum of the newly formed United Nations. ${ }^{18}$ And it was Karel Lisicky, representing Czechoslovakia in UNSCOP - the United Nations Special Committee for Palestine, who gathered information and then formulated the groundwork for the United Nations Resolution No. 181/II from November $29^{\text {th }}$, 1947, known as the Partition Plan for Palestine. ${ }^{19}$ The resolution, then, provided a legal base for the existence of two independent states - Jewish and Arab. ${ }^{20}$

As time has shown, these were not only diplomatic battles of the world-size calibre, but also battles of a calibre much smaller. These battles and struggles took place between players in the Czechoslovak post-February politics, and their theatre was the sphere of Czechoslovak arms industry. When the Communist party seized power, traditionally western-ori-

15 Základ novodobých česko-izraelských vztahů se zrodil před 90 lety. Postaral se o to TGM, https://ct24.ceskatelevize.cz/svet/2089059-zaklad-novodobych-cesko-izraelskychvztahu-se-zrodil-pred-90-lety-postaral-se-o-tgm, last visited on 2.6.2020.

16 About Hilsner Affair, see Martin Wein, History of the Jews in the Bohemian Lands, E.J. Brill, New York 2015, 40-42; Pavel Kosatík, Jiný T. G. M., Paseka, Praha 2018, 136-141; about Masaryk's views see also Tomáš Garrigue Masaryk, Nutnost revidovati proces polenský, Praha 1899.

17 קהילנט, http://www.kfar-masaryk.org.il/mainsite.asp?sitename=masaryk, last visited on 2. 6. 2020.

18 Moshe Yegar, Československo, sionismus, Izrael, Victoria Publishing, Praha 1997, 82-84.

19 Tomáš Habermann, Československo a Izrael 1947-1949: Léta př́telství, Master’s degree diploma theses, Charles' University in Prague, Praha 2001, 29; M. Yegar, 83.

20 Part I, Letter A, Article 3 of A/RES/181(II), Future government of Palestine, 29. 11. 1947. 
ented factories started losing their markets. It became more and more of an economic necessity to find a suitable trade outlet - or else the economic recess would start to threaten the otherwise stable sector. ${ }^{21}$ Therefore, the previously mentioned calibre can be calculated quite precisely as the $7,92 \mathrm{~mm}$ calibre - the one used by both rifles and machine guns produced by Zbrojovka Brno, the largest arms and ammunitions national factory that sold these articles to the Jewish community of Palestine, and subsequently to Israel.

These contracts were acted upon even though the states were, according to resolution 181/II, "(...) to refrain from taking action which might hamper or delay the carrying out of (...) recommendations, (...) ${ }^{\times 22}$. This formulation is sometimes misinterpreted as an imposition of an embargo on Palestine. But the embargo itself could be (and was) imposed only by a Security Council resolution.

There are three crucial resolutions to consider when deciding whether or not an embargo on export of arms and ammunition to the Middle East really existed. In the first one, S/RES/42 of March $5^{\text {th }}, 1948$, the Security Council „appeals to all Governments and Peoples, particularly in and around Palestine, to take all possible action to prevent or reduce such disorders as are now occurring in Palestine."23 This is not to be counted as imposing an embargo, especially with regard to later practice, forged during these difficult formative years of the United Nations, which was rigorously observed. ${ }^{24}$ To "activate" articles 41 and 42 of the UN Charter ${ }^{25}$, a sort of warning - the formal determination of existence of any threat to the peace, breach of the peace, or act of aggression - has to be issued first. ${ }^{26}$ Only after such a warning can a measure be undertaken under the article 41 , and then subsequently under the article 42 . And one such measure under the article 42 of the UN Charter is an embargo.

The process therefore must be: 1. determination ("warning"), 2. action under article 41 of the Charter, 3. action under article 42. The resolution 42 of March $5^{\text {th }}$ ought to be viewed as the first step - a determination of threat to the peace, although the Security Council does not

21 Archiv Bezpečnostních složek (Archive of Security Services, further as “ABS”), 425365-1, 7.

22 Preamble, A/RES/181 (II).

23 Art. 4, S/RES/42 (1948) of March 5 ${ }^{\text {th }}, 1948$.

24 Miroslav Potočný, Jan Ondřej, Mezinárodní právo veřejné: zvláštní část, C.H. Beck, Praha 2011, 299.

25 United Nations Charter, https://www.un.org/en/sections/un-charter/un-charter-fulltext/, last visited on 4.8.2020, furthermore, as "UN Charter".

26 See Art. 39 UN Charter. 
explicitly state it. The next resolution, S/RES/46 (1948) of April 17 $7^{\text {th }}, 1948$, appeals on all persons and organizations in Palestine and especially the Arab Higher Committee and Jewish Agency to "refrain from importing or acquiring or assisting or encouraging the importation or acquisition of weapons and war materials". ${ }^{27}$ That is clearly an imposition of a measure under article 41 of the Charter, but this measure is not directed towards all members of the UN, and even less towards third countries. However, the Security Council opened doors to measures under article 42 - and waited patiently to step into them.

That happened on May $29^{\text {th }}$, when the next resolution called for an embargo on Palestine. ${ }^{28}$ But Palestine effectively ceased to exist on May $15^{\text {th }}$, after the British Mandatory Administration withdrew its forces. There were already one or two successive states struggling to gain recognition, thus the embargo was incorrectly formulated and as a legal act ineffective, null and void, even. As for Czechoslovakia, more important is the fact that neither her, nor any other country was ever accused of breaking such an embargo on any forum.

As for the legality of the executed arms and ammunitions contracts, Czechoslovakia was bound by another international legal document: Convention for the Control of the Trade in Arms and Ammunition from $1919^{29}$. Conforming to this convention, Czechoslovakia had come up with a system of permits or licenses for exportation of arms and ammunition. Czechoslovakia not only devised such a system but rigorously observed it as far as we can say from the extant, fragmentary base of documents we have at our disposal. ${ }^{30}$

The system itself included approvals of various authorities bound by $\$$ 24 subsection 3 of the Act No. 131/1936 Coll., on the Defense of the State. The process usually depended on the material that was the object of a contract. Therefore, we can observe the influences of the general staff of the Army and Air force ${ }^{31}$, ministries of national defence, foreign affairs, and

27 Art. 1, letter c), S/RES/46 (1948) of April 17 th 1948.

28 Art. 4, S/RES/50 (1948) of May 29 1948.

29 ABS 425_239_01_0136; Full text of the Treaty is available from: Convention for the Control of the Trade in Arms and Ammunition from 1919, Supplement: Official Documents, The American Journal of International Law, 15/1921, 297-313.

30 For example: Copy of export permit No. 830632, Moravskýzemskýarchiv (Moravia Land Archive), Fond K433-supplement 2005, folder Zbrojovka Brno, s. p., 1946-1952, collection 37, inv. No. 93; "Obchodní korespondence s Palestinou" (further as "MZA-PA"), fol. 537-538; Copy of export permit No. 830878, ibid.

31 Document reference: "Důvěrné Izrael z MNO 1948-1953", Archiv Vojenského historického ústavu (Archive of Military History Institute Prague), No. 690 taj., (further as "VHÚ"); Z. Klíma, 36. 
foreign trade ${ }^{32}$ Trade operations were also endorsed by the government by its Prime Minister, the communist party chairman, Klement Gottwald. ${ }^{33}$

Economic necessity and the policy of the Communist Party that tried to act in accordance with the USSR Middle-Eastern policy of weakening the "imperialist influence" in the region, along with a history of pro-Jewish sentiment displayed by the authorities, were not the only factors that played a role in the 1948 operations. After all, a considerable role was played by simple human relationships and individual motivations, usually consisting of more than one of the abovementioned factors. It was probably a Czech-born Jew, Otto Felix, who made it possible for Ehud Avriel ${ }^{34}$ - one of the emissaries of the Jewish Agency for Palestine sent to Europe to look for arms - to negotiate with Zbrojovka Brno, thanks to his pre-war connections. ${ }^{35}$

The first contract concluded on January $20^{\text {th }}, 1948$ without any legal flaw under the Act No. 946/1811 Coll., the Civil Code; it called for a delivery of 4500 Mauser Kar 98k rifles (Zbrojovka produced them as "P-18s"), 200 MG-34 machine guns and 5040000 rounds of 7,92 mm ammunition. ${ }^{36}$ This material reached Palestine partly by chartered flight and partly through Yugoslavian ports of Vukovar and Šibenik, just in time to help the Jewish community break the siege of Jerusalem during operation Nachshon. ${ }^{37}$ Generally speaking, the first shipments went the same way from Bratislava to Vukovar, then to Šibenik, and finally to Palestine.

32 Copy of export permit No. 830632, MZA-PA, fol. 537-538; Copy of export permit No. 830878 , ibid.

33 VHÚ, Reference No. 12526-taj-pkm-1948, fol. 40; Bulínová et al., 88, No. 24; Bulínová et al., 110, No. 27.

34 About him, see Ehud Avriel, Open the gates!: A personal story of "illegal" immigration to Israel, Atheneum, New York 1975, 331. et seq; revisited and extended in article Ehud Avriel, „Prague and Jerusalem: the Era of Friendship”, Avigdor Dagan, Gertrude Hirschler, Lewis Weiner (eds.), The Jews of Czechoslovakia: historical studies and surveys, The Jewish Publication Society of America: Society for the History of Czechoslovak Jews, Philadelphia 1984, 551-565; Frank Haggai, Zdeněk Klíma, Yossi Goldstein, "The First Israeli Weapons Procurement Behind the Iron Curtain: The Decisive Impact on the War of Independence", Israel Studies, 22/2017, 132; David Bercuson, The Secret Army, T. H. Best, Toronto 1983, 30; see also A. Krammer, 59.

35 F. Haggai, Z. Klíma, Y. Goldstein, 131; A. Krammer, 61; Leonard Slater, The pledge, Pocket Books, New York 1971, 143; Benjamin Kagan, The Secret Battle for Israel, American Book-Stratford Press, Cleveland - New York 1966, 44-45.

36 "Contrat", MZA PA, fol. 372; Order ratification 410001/zazbr, Národní archiv (National Archive), Fond 947 "Československé závody kovodělné a strojírenské n. p. 1945-1949”, reference No. 16, Collection 5 "Bezpečnost”, Folder “Zbrojovka Brno, zahraniční prodej zbraní”; See also: A. Krammer, 60-61.

37 About operation Nachshon which started on March 6 ${ }^{\text {th }}$, see E. Cohen, 21-22; Chaim Herzog, Arabsko-izraelské války: válka a mír na Blizkém východě od války za nezávislost v roce 1948 po současnost, NLN, Praha 2008, 33. et seq.; see also Z. Klíma, 33. 
Apart from arms, Czechoslovakia agreed to sell fighter planes to the Jewish community, and subsequently Israel. The first contract, concluded also under the Act No. 946/1811 Coll., the Civil Code, on 10 Avia S-199 (modified Messerschmitt Bf-109) was concluded on Friday, April 23 ${ }^{\text {rd }}$, 1948. ${ }^{38}$ The Czech side was represented by Czechoslovak Metal and Engineering Works (Československé závody kovodělné a strojírenské), the Jewish by Ehud Avriel and Otto Felix. ${ }^{39}$ Czechoslovak Metal and Engineering Works also pledged themselves to train 10 pilots sent by the Jewish Agency to fly the Avias. ${ }^{40}$ On June $21^{\text {st }}, 1948$, an additional contract on 15 more Avias was concluded. ${ }^{41}$

Planes were shipped to Israel from a military airport near Žatec in Czechoslovakia, which had been lent to the Jewish Agency by the Czechoslovak Air Force. ${ }^{42}$ The course was abridged, on request of the traineesso they could be engaged in a fight for Israel's independence as soon as possible. ${ }^{43}$

This course for piloting the Avias was only the first of the courses Czechoslovakia would offer to volunteers willing to go to fight for Israel. As it was already mentioned, apart from the retraining course, volunteers could undergo basic pilot training, ${ }^{44}$ advanced pilot training, ${ }^{45}$ a course for flight mechanics and radio operators ${ }^{46}$, and courses for paratroopers and tank operators. This was possible due to the document negotiated by $\mathrm{Mr}$ Felix and signed by the chief of the Czechoslovak Air Force division, general Alois Vicherek, chief of general staff, Bohumír Boček, secretary of defence, general Ludvík Svoboda, and, finally, Prime Minister Klement Gottwald. ${ }^{47}$

The largest training action produced a whole unit in the size of a ready-to-deploy brigade. The training was executed on grounds of a con-

38 VHÚ, document concerning the C-210 fighter planes; the same document is printed in edition by Bulínová et al., 89, No. 25. Everything further stated about the document therefore counts the same for original; see also Z. Klíma, 35.

39 Bulínová et al., 89, No. 25; Z. Klíma, 35-36.

40 About training see e. g. R. Gandt, 72-74; E. Cohen, 23-25; Ezer Weizman, On Eagle's Wings, Weidenfeld \& Nicolson, London 1976, 61. et seq.; Jeffrey Weiss, Craig Weiss, I am My Brother's Keeper: American Volunteers in Israel's War of Independence 1947-1949, Schiffer, Atglen 1998, 110; Z. Klíma, 130. et seq.

41 Bulínová et al., 117, No. 36; Z. Klíma, 38. et seq.

42 See article 5, ABS 425_360_6_0005; Bulínová et al., 97, No. 26; A. Krammer, 88-89; J. Weiss, C. Weiss, 111-112; R. Gandt, 90-95; Z. Klíma, 74 et seq.

43 Above, and Beyond, 36:17; E. Weizman, 63-64; R. Gandt, 78-80.

44 ABS 425_360_6_0005; Bulínová et al., 98, No. 26; Z. Klíma, 146. et seq.

45 Ibid.

46 Ibid.; see also A. Krammer, 92.

47 ABS 425_360_6_0004, Bulínová et al., 99, No. 26; Z. Klíma, 36. 
tractual document, signed between the envoys of Israel and an independent Czechoslovak intermediary, who guaranteed that the action would be realised by the Czechoslovak authorities. ${ }^{48}$ The document also specified, apart from other things, conditions for deployment of members of the brigade in Israel, including compensations for their injuries and/or death. ${ }^{49}$ The unit consisted of volunteers both from Czechoslovakia and from other countries - among them were even 4 citizens of Yugoslavia: private Isidor Deutsch of an artillery company, private Sado Bachar of the sapper company, and privates Lazar Israel and Aron Avramovic of the tank platoon. Two officers from the Yugoslavian army who were actively deployed in the Second World War appeared in the school for commanding officers - Markus Toba and Josef Jakubovic. ${ }^{50}$

Let us step back to fighter planes - the Avias were not the only ones sent to Israel that year. In accord with the contracts from September $7^{\text {th }} 51$ and November $8^{\text {th }}, 1948^{52}, 62$ Spitfire Mk. IXE were sold to the Israelis. ${ }^{53}$ Czechoslovakia originally acquired those Spitfire planes as thanks for the service of many Czechoslovaks in RAF during the Second World War and now, when the orientation of the country shifted from West to East, there was no reason to keep them in the arsenal. ${ }^{54}$

In autumn 1948, the situation grew in uncertainty in both Israel and Czechoslovakia - so it was decided in mutual agreement that it should be best to transport the Spitfires to Israel as soon and as quickly as possible. The necessary modifications were made thanks to the wit and resource-

48 Bulínová et al, 122, No. 37; see also: Yaacov Ro’I, Soviet decision making in practice: the USSR and Israel, 1947-1954, Transaction Books, New Brunswick - New Jersey 1980, 144-145; A. Ilan, 167-168.

49 Bulínová et al., 120-122, No. 37.

50 They can be found in a register of brigade's members in ABS 425-360-1; Bulínová et al., 337-365; the spelling of the names is as used in the document. During our team's research, we came across names of members that are not mentioned there. It should be amended in the future, especially based on the individual testimonies and personal records of former members and their families.

51 Bulínová et al., 146, No. 51.

52 Bulínová et al., 221, No. 86, Bulínová et al., 223, No. 86.

53 Bulínová et al., 146, No. 51; Bulínová et al., 221, č. 86, Bulínová et al., 223, č. 86; see also A. Krammer, 99; A. Ilan, 169-170; Z. Klíma, 50. et seq.

54 A. Yofe, s. 13; Miroslav Irra, Výzbroj ČS. vojenského letectva 1945-1950, Q Point, Praha 2018; Miroslav Irra, "Spitfajr": Supermarine Spitfire L.F. Mk. IXE v československém letectvu, Jakab, Nevojice 2016; Jiří Rajlich, Czechoslovak Spitfires in detail: the history of Czechoslovak Spitfires LF.Mk.IXE from 1945 to present, RAK, Praha 2002; František Kořán et al., Spitfire LF.Mk.IX in detail: Spitfires LF.Mk.IX from the Czech National Technical Museum's collection in Kbely Aviation Museum exhibition and of the IWM's collection in Duxford, Wings and Wheels Publications, Praha 2002. 
fulness of the Machalniks (especially Sam Pomerance) and the Israelis and now the Spitfires could fly the distance between Czechoslovakia and Israel with only one stop. ${ }^{55}$

After a lengthy negotiation, the Israelis obtained permission to use the airport of Nikšić in Yugoslavia, nowadays in Montenegro. ${ }^{56}$ The two operations during which the Spitfires were more or less successfully ferried to Israel were named after a suntan lotion advertised in newspapers in 1948 - Velvetta. ${ }^{57}$ And it was the beginning of the second wave (called Velvetta II) that saw the events described at the beginning of this paper.

Arms shipments started to dwindle at the begining of the new year - 1949. The "Hagana brigade" leaves Czechoslovakia in the spring of that same year. ${ }^{58}$ Cooperation between the two states is beginning to deteriorate. Again - more than one factor is probably to blame. First and foremost - the main goal was accomplished: the State of Israel emerged from its baptism by the fire of war alive. Therefore, the demand changes - there is a more urgent need for proverbial ploughshares than swords.

The political situation changes distinctively: instead of the radical Communist Party of Israel, a favourite of Stalin and USSR, the general election to Knesset in January 1949 is won by the Labour party, led by David Ben Gurion. ${ }^{59}$ The first government of the new state then accepts an investment loan of $\$ 100000000$ from the USA. ${ }^{60}$ That definitely shifts Israel away from Stalin's grace and a group of "people's democracies". The Eastern bloc will hereafter support countries of the Arab League.

An epilogue to the events of the summer of 1948 can be seen in the politically motivated show trials sweeping through the Eastern bloc in 1950's, starting in Romania, moving through Bulgaria and Poland, reaching Czechoslovakia and culminating in the so-called "Slánský trial". The rhetoric of these trials, officially "antizionist" is led by antisemitism and, as such, the engagement of those involved in Israeli operations in Czechoslovakia is counted as an aggravating circumstance for them. And so it happened that on the gallows of Pankrác penitentiary the secretary of for-

55 A. Yofe, 13-14; R. Gandt, 234-235; A. Cohen, 474.

56 A. Yofe, 13; D. Bercuson, 173-174; Bojan B. Dimitrijević, Jugoslovensko ratno vazduhoplovstvo 1942-1992, Institut za savremenu istoriju, Beograd 2006, 57; S. Aloni, B. Cull, D. Nicole, 234; Ibid., 294; R. Gandt, 237-241.

57 see. A. Krammer, 103; B. Dimitrijević, 57-59; S. Aloni, B. Cull, D. Nicole, 243; R. Gandt, 237-241. About operation see also S. Aloni, B. Cull, D. Nicole, 292-295.

58 Bulínová et al., 189-190, No. 68; J. Dufek, K. Kaplan, V. Šlosar, 80; J. Dufek, K. Kaplan, V. Šlosar, 188.

59 A. Krammer, 141.

60 Ibid., 140. 
eign affairs Vladimír Clementis and the Secretary-General of the Central Bureau of Communist Party, a Jew, Rudolf Slánský, were hanged, among others. ${ }^{61}$ It is probable that none of them really played an active major role in the whole operation - but even though they did not move things along, they certainly allowed them to move. ${ }^{62}$ However, the Slánský trial is only a peak - many other actors of the events discussed here ended up either in jail or persecuted in some other way. ${ }^{63}$

As it was demonstrated above, all the accusations of illegality by the communist persecution machine were - not surprisingly - false. Every contract, every action and every step was undertaken with vigorous effort to uphold legality on all levels imaginable. Of course, there is no doubt that hand in hand with that went the effort to raise as little suspicion as possible - but it seems that it was a secondary effort in comparison to the former.

The Czechoslovak-Israeli relationships grew colder and colder, until they were definitely severed in the tide of the Six-Day War in 1967. Their renewal starts in the 1990's, after a democratic revolution. In spite of that, it is not unusual to encounter a rifle hanging on a wall in an Israeli home that was sold under the signature "P-18" by Zbrojovka Brno in 1948. And among the most prized artefacts of the Hatzerim Air Force Museum is Ezer Weizmann's black Spitfire, ferried through Nikšić from Czechoslovakia. Its last flight was a ceremonial one - during the former president's funeral in 2005. ${ }^{64}$

There is one more Spitfire in Hatzerim - it bears its original colours with the star of David, as it flew them from Yugoslavia. The pilot who was then in charge of delivering it to Israel was none other than Dani Shapira.

\section{BIBLIOGRAPHY}

\section{PRIMARY SOURCES:}

Act No. 131/1936 Coll., on the Defense of the State.

Archiv Bezpečnostních složek (Archive of Security Services)

A/RES/181(II), Future government of Palestine, 29.11.1947.

61 About the trial, see e. g. Karel Kaplan, Zpráva o zavraždění generálního tajemníka, Mladá fronta, Praha 1992.

62 See also A. Krammer, 68. et seq.; Y. Ro'i, 150. et seq.

63 See Kaplan; K. Bartošek.

64 Nadav Berger, Ofri Aharon, “Ezer Weizman's Black Spitfire Back in The Air”, Warbird Digest, http://warbirdsnews.com/warbirds-news/ezer-weitzmans-black-spitfire-air. html, last visited on 2. 6. 2020. 
Convention for the Control of the Trade in Arms and Ammunition from 1919, Supplement: Official Documents, The American Journal of International Law, 15/1921, 297-313.

“Důvěrné Izrael z MNO 1948-1953”, Archiv Vojenského historického ústavu (Archive of Military History Institute Prague)

Interview with Dani Shapira, Vojtěch Vrba (interviewer), Haifa, 25.3.2018.

Interview with MUDr. Michael Lavi roz. Lebovič (1913-2015.), Adam Hradilek (interviewer), Pamět národa (cit. 25.2.2019.), Ascalon, 7. 6. 2006, <https:// www.pametnaroda.cz/cs/lavi-roz-lebovic-michael-1913>

Marie Bulínová et al. (eds.), Československo a Izrael 1945-1956: dokumenty, Ústav pro soudobé dějiny AV ČR, Praha 1993.

"Obchodní korespondence s Palestinou", Moravský zemský archiv (Moravia Land Archive), Fond K433-supplement 2005, folder Zbrojovka Brno, s. p., 1946-1952, collection 37, inv. No. 93

S/RES/42 (1948) of March $5^{\text {th }}, 1948$.

S/RES/50 (1948) of May 29 1948.

S/RES/46 (1948) of April 17 th 1948.

The United Nations Charter, https://www.un.org/en/sections/un-charter/un-charter-full-text/, last visited on 4.8.2020.

Yad Vashem, The World Holocaust Remembrance Center, Archives, O.59, Collection of Testimonies and Documents about the Participation of Czechoslovakian Jewry in the War against Nazi-Germany, File No. 9, Božena Elisheva Hermann-Cohen, interview from 17.1.1973.

Yad Vashem, The World Holocaust Remembrance Center, Archives, O.59, Collection of Testimonies and Documents about the Participation of Czechoslovakian Jewry in the War against Nazi-Germany, File No. 71, Samson Šachta Schaechter, interview from 14.4.1973.

\section{SECONDARY SOURCES:}

Above and Beyond [movie], directed by Roberta Grossman, USA 2014.

קהילנט, >http://www.kfar-masaryk.org.il/mainsite.asp?sitename=masaryk>, last visited on 2.6.2020.

Základ novodobých česko-izraelských vztahů se zrodil před 90 lety. Postaral se o to TGM, <https://ct24.ceskatelevize.cz/svet/2089059-zaklad-novodobychcesko-izraelskych-vztahu-se-zrodil-pred-90-lety-postaral-se-o-tgm>, last visited on 2.6.2020.

Schlomo Aloni, Brian Cull, David Nicole, Spitfires Over Israel, Grub Street, London 1994.

Ehud Avriel, Open the gates!: A personal story of "illegal" immigration to Israel, Atheneum, New York 1975. 
Ehud Avriel, „Prague and Jerusalem: the Era of Friendship”, Avigdor Dagan, Gertrude Hirschler, Lewis Weiner (eds.), The Jews of Czechoslovakia: historical studies and surveys, The Jewish Publication Society of America: Society for the History of Czechoslovak Jews, Philadelphia 1984.

Karel Bartošek, Český vězeň: svědectví politických vězeňkyň a vězňủ let padesátých, šedesátých a sedmdesátých, Paseka, Praha 2001.

David Bercuson, The Secret Army, T. H. Best, Toronto 1983.

Nadav Berger, Ofri Aharon, "Ezer Weizman's Black Spitfire Back in The Air", Warbird Digest, http://warbirdsnews.com/warbirds-news/ezer-weitzmansblack-spitfire-air.html, last visited on 2. 6. 2020.

Avi Cohen, The History of Israeli Air Force in The War for Independence 15 July 1948 - 15 October 1948 (hebrew), Ministry of Defence, Tel-Aviv 2004.

Eliezer Cohen, Israel's Best Defense: The First Full Story of the Israeli Air Force, Orion Books, New York 1990.

Bojan B. Dimitrijević, Jugoslovensko ratno vazduhoplovstvo 1942-1992, Institut za savremenu istoriju, Beograd 2006.

Jiř́i Dufek, Karel Kaplan, Vladimír Šlosar, Československo a Izrael v letech 19471953, Doplněk, Praha 1993.

Robert Gandt, Angels in the Sky, W. W. Norton \& Co. Ltd., New York 2017.

Tomáš Garrigue Masaryk, Nutnost revidovati proces polenský, Praha 1899.

Tomáš Habermann, Československo a Izrael 1947-1949: Léta př́telství, Master’s degree diploma theses, Charles' University in Prague, Praha 2011.

Frank Haggai, Zdeněk Klíma, Yossi Goldstein, “The First Israeli Weapons Procurement Behind the Iron Curtain: The Decisive Impact on the War of Independence", Israel Studies, vol. 22, 3/2017, 125-152.

Chaim Herzog, Arabsko-izraelské války: válka a mír na Blizkém východě od války za nezávislost v roce 1948 po současnost, NLN, Praha 2008.

Amitzur Ilan, The origin of the Arab-Israeli arms race: arms, embargo, military power and decision in the 1948 Palestine war, New York University Press, New York 1996.

Miroslav Irra, "Spitfajr": Supermarine Spitfire L.F. Mk. IXE v československém letectvu, Jakab, Nevojice 2016.

Miroslav Irra, Výzbroj ČS. vojenského letectva 1945-1950, Q Point, Praha 2018.

Benjamin Kagan, The Secret Battle for Israel, American Book-Stratford Press, Cleveland - New York 1966.

Vilém Kahan, "Vilém Kahan par lui méme (extraits des entretiens de 1984)", Vilém Kahan (ed.), Bibliography of the Communist International (1919-1979), E.J. Brill, New York 1990, 55-67.

Karel Kaplan, Zpráva o zavraždění generálního tajemníka, Mladá fronta, Praha 1992. 
Zdeněk Klíma, Československý podíl na vzniku izraelského vojenského letectva a jeho operační činnosti v 1. izraelsko-arabské válce: proseminární práce, Praha 1995.

František Kořán et al., Spitfire LF.Mk.IX in detail: Spitfires LF.Mk.IX from the Czech National Technical Museum's collection in Kbely Aviation Museum exhibition and of the IWM's collection in Duxford, Wings and Wheels Publications, Praha 2002.

Pavel Kosatík, Jiný T. G. M., Paseka, Praha 2018.

Arnold Krammer, The forgotten friendship: Israel and the Soviet Bloc, 1947-53, University of Illinois Press, Urbana 1974.

Jiří Kovtun, Tajuplná vražda: př́pad Leopolda Hilsnera, Sefer, Praha 1994.

Yaacov Markovitzky, Machal: Overseas Volunteers in Israel's War of Independence, Jerusalem 2003, [Internet Edition 2007] http://www.palyam.org/Volunteers/MachalPdf.pdf, last visited on 1. 6. 2020.

Ivo Pejčoch, "Výcvik př́íslušníků brigády Hagana v Československu”, Historie a vojenství, 60/2011, 4-21.

Miroslav Potočný, Jan Ondřej, Mezinárodní právo veřejné: zvláštní část, C.H. Beck, Praha 2011.

Jiří Rajlich, Czechoslovak Spitfires in detail: the History of Czechoslovak Spitfires LF.Mk.IXE from 1945 to present, RAK, Praha 2002.

Yaacov Ro'I, Soviet decision making in practice: the USSR and Israel, 1947-1954, Transaction Books, New Brunswick - New Jersey 1980.

Vic Shayne, Ups and Downs With No Regrets: The Story of George Lichter, iUniverse, Bloomington 2012.

Leonard Slater, The pledge, Pocket Books, New York 1971.

Martin Wein, History of the Jews in the Bohemian Lands, E.J. Brill, New York 2015.

Jeffrey Weiss, Craig Weiss, I am My Brother's Keeper: American Volunteers in Israel's War of Independence 1947-1949, Schiffer, Atglen 1998.

Ezer Weizman, On Eagle’s Wings, Weidenfeld \& Nicolson, London 1976.

Moshe Yegar, Československo, sionismus, Izrael, Victoria Publishing, Praha 1997.

Alex Yofe, Spitfire Mk. IX in the Israeli Air Force Service 1948-1956, White Crow, San Jose 2007. 


\title{
Мр Војтех ВРБА*
}

\author{
ДРЖАВИ ИЗРАЕЛ, ОД ЧЕХОСЛОВАЧКЕ: \\ УВОД У ПРАВНЕ АСПЕКТЕ ЧЕХОСЛОВАЧКЕ \\ ПОМОКИ ДРЖАВИ ИЗРАЕЛ ОД 1947-1949.
}

\section{Сажейак}

Рад уводи читаоца у основне правне аспекте чехословачке помоћи Држави Израел у интервалу између 1947-1949. Чехословачка у овом периоду извози оружје, муницију, ловачке авионе и остали ратни материјал јеврејској заједници на Блиском истоку. Постојао је и значајан број волонтера који је у Чехословачкој прошао кроз разноврсне обуке. Курсеви су подразумевали обучавање пилота, механичара за одржавање ваздухоплова, падобранаца, итд. Све ове операције су имале своје правне особине и аспекте. Рад те аспекте анализира уопштено. Као извори коришћени су правни акти и архивска документа, интервјуи, секундарни извори и литература - мемоарска, тако и историографска.

Кључне речи: Чехословачка. - Израел. - Правна истиорија. - Рай за независности у Израелу.

Рад приспео / Paper received: 7.6.2020. Прихваћен за објављивање / Accepted for publication: 10.8.2020.

* Докторанд Правног факултета Западночешког универзитета у Пилсену, vrbav@kpo.zcu.cz.

Рад је написан у оквиру пројекта "ZČU SGS-2020-025 Law in the Course of Time 3”, на Катедри за правну историју Правног факултета Западночешког универзитета у Пилсену. 